\title{
Selecting ecotonal landscape units on Meridional Plateau, Southern Brazil
}

\author{
Selección de unidades ecotonales de paisaje en Plató Meridional, Sur de Brasil
}

\author{
Rosemeri Segecin Moro $^{\text {a*, }}$ Ingrid Aparecida Gomes ${ }^{\text {b, Tiaro Katu Pereira }}{ }^{\text {b }}$ \\ *Corresponding author: ${ }^{a}$ Universidade Estadual de Ponta Grossa, Programa de Mestrado em Geografia, \\ Ponta Grossa, PR - Brazil, moro.uepg@gmail.com \\ ${ }^{\mathrm{b}}$ Universidade Estadual de Ponta Grossa, Programa de Mestrado em Geografia, Ponta Grossa, PR - Brazil.
}

\begin{abstract}
SUMMARY
The Escarpa Devoniana environmental protection area, located in the Meridional Plateau of South Brazil, supports a high diversity mosaic of native araucaria (Araucaria angustifolia) forests and grasslands patches. In order to conduct studies of its dynamics, the biodiversity of grassland-forest ecotones in South Brazil Project team has been developing a methodological approach for sorting ecotonal areas for sampling. This essay validates this methodology to the major grasslands occurrence area in the Brazilian Atlantic Forest Biome, the Campos Gerais region. The entire area was divided into a $1 \mathrm{x} 1 \mathrm{~km}$ grid that was overlayed with vegetation typology files. The criteria for quadrat selecting were: (a) $25 \%$ or more of forest remnants; (b) $25 \%$ or more of grasslands remnants; (c) at least $20 \%$ of contact between them. The non-supervisioned classification potential ecotonal areas were validated through visual checking in a high resolution qualitative way, always by the same operator. The quadrats could be achieved by the researchers in a $* . k m z$ file, which allows someone selecting them in the Google Earth platform.
\end{abstract}

Key words: landscape ecology, Campos Gerais, GIS, sampling methods.

\section{RESUMEN}

El área de preservación ambiental de la Escarpa Devoniana, situado en la meseta meridional del Brasil, presenta un mosaico de gran diversidad de bosques de araucaria (Araucaria angustifolia) y pastizales nativos. Para llevar a cabo estudios de su dinámica, el equipo del proyecto de biodiversidad de ecotonos de bosques y pastizales en el sur de Brasil ha desarrollado un enfoque metodológico para ordenar áreas ecotonales de muestreo. Este ensayo valida la metodología para la zona de ocurrencia de grandes pastizales en el bioma de bosque atlántico, la región de Campos Gerais. Toda el área fue dividida en cuadrículas de 1 x $1 \mathrm{~km}$ cubiertas con archivos de tipología de vegetación. Los criterios para la selección de cuadrículas fueron: (a) $25 \%$ o más de los restos de bosque; (b) $25 \%$ o más de los restos de pastizales; (c) al menos el $20 \%$ de contacto entre ellos. La clasificación no supervisada de áreas potencialmente ecotonales fue validada a través de comprobación cualitativa visual de alta resolución, siempre por lo mismo operador. Los investigadores podrían obtener las cuadrículas en un archivo con formato *.kmz el cual permite su selección en la plataforma de Google Earth.

Palabras clave: ecología de paisajes, Campos Gerais, SIG, métodos de muestreo.

\section{INTRODUCTION}

Grasslands in southern Brazil are natural ecosystems present in this region prior to the forest expansion in the Late Quaternary (Behling and Lichte 1997, Behling and Pillar 2007). Grasslands form ecotones with araucaria (Araucaria angustifolia (Bertol.) Kuntze.) forest isolated rounded patches, linear riparian forests, or larger forests over slopes (Moro and Carmo 2007).

The natural grasslands dynamic are associated with water and soil conditions (Curcio 2006) and with disturbances such as fire and pasture (Overbeck et al. 2007). Investigations on the araucaria forest expansion over the grasslands in the Campos Gerais region, in the Paraná State, are being conducted with a proposed, not published yet, methodology for sorting areas developed to the Pam- pas Biome, in Rio Grande do Sul${ }^{1}$. In that region, forests spread mainly from their edge over the open areas (Oliveira and Pillar 2004), or from little woody nucleous not far from the forest (Duarte et al. 2007).

This essay validates this geographic information system methodology to select and sort ecotonal areas on the major grasslands occurrence in the Brazilian Atlantic Forest Biome, the Campos Gerais region.

\section{METHODS}

The systematic and standardized approach to select suitable sampling units combined stratification and ran-

\footnotetext{
${ }^{1}$ Hasenack H, E Weber, E Vélez, R Cardoso. 2011. Procedimento para seleção de unidades amostrais de paisagem (UAPs) em campos e em ecótonos campo/floresta no Rio Grande do Sul - Projeto SISBIOTA.
} 
domization from knowledge about the current distribution and spatialization of grasslands and forests ecotones. For this, we used the database related to the Escarpa Devoniana environmental protection area ('APA' in Portuguese), a conservation unit of extensive use with 392,363 ha (SEMA/IAP 2004). Images from 2004 were a fusion of Landsat 7 satellite bands. Analyses were performed by the software ArcGIS 9.x using the vector-based landscape analysis tools extension (ESRI 2006).

We adopted in the first step, as reference, a standardized spatial grid of 10x10 km recommended by the Brazilian Government (Serviço Florestal Brasileiro/ Ministério do Meio Ambiente) for sampling to the National Forestry Inventory. According to them, this resolution allowed ecotone delimitations in several different regional landscapes no matter the predominant matrix. Thiessen polygons resulted from the equidistant lines interacting between points and the environmental protection area limits were overlayed with vegetation typology files of the environmental protection area. The attribute table contained patches information, as patch identification number, grid code, use class (araucaria forest, grasslands, silviculture, agriculture, and water bodies), total area ( $\mathrm{m}^{2}$ and hectares), and perimeter.

Using the class attribute, the criteria for quadrat selection were: (a) $25 \%$ or more of forest remnants; (b) $25 \%$ or more of grasslands remnants. These arbitrary criteria were considered enough to provide a good probability of grasslands and forests were in contact. As the quadrats selected this way could not be real ecotonal areas, once they could be apart, validation of the non-supervisioned classification was conducted in a qualitative way, always by the same operator, through visual checking of the contact between grasslands and forests patches. Every quadrat was analyzed by means of the more recent images of Google Earth and only the contact of at least $20 \%$ of the two vegetation were considered ecotones for our purposes. This criterion was arbitrary too, considering the finest scale of the mapping interpretations and the field necessities for replica plotting settlement.

\section{RESULTS}

The $8510 \times 10 \mathrm{~km}$ polygons have covered 850,000 ha, so we perceived that this grid size covered much more than the environmental protection area (figure 1A). Besides, the initial proposed resolution, of 30 meters, was unable to discriminate some small ecotones in this region and, in spite of the Brazilian government technical recommendations, a new delimitation was necessary. So each polygon was divided again, this time in a 1x1 km grid with 4,647
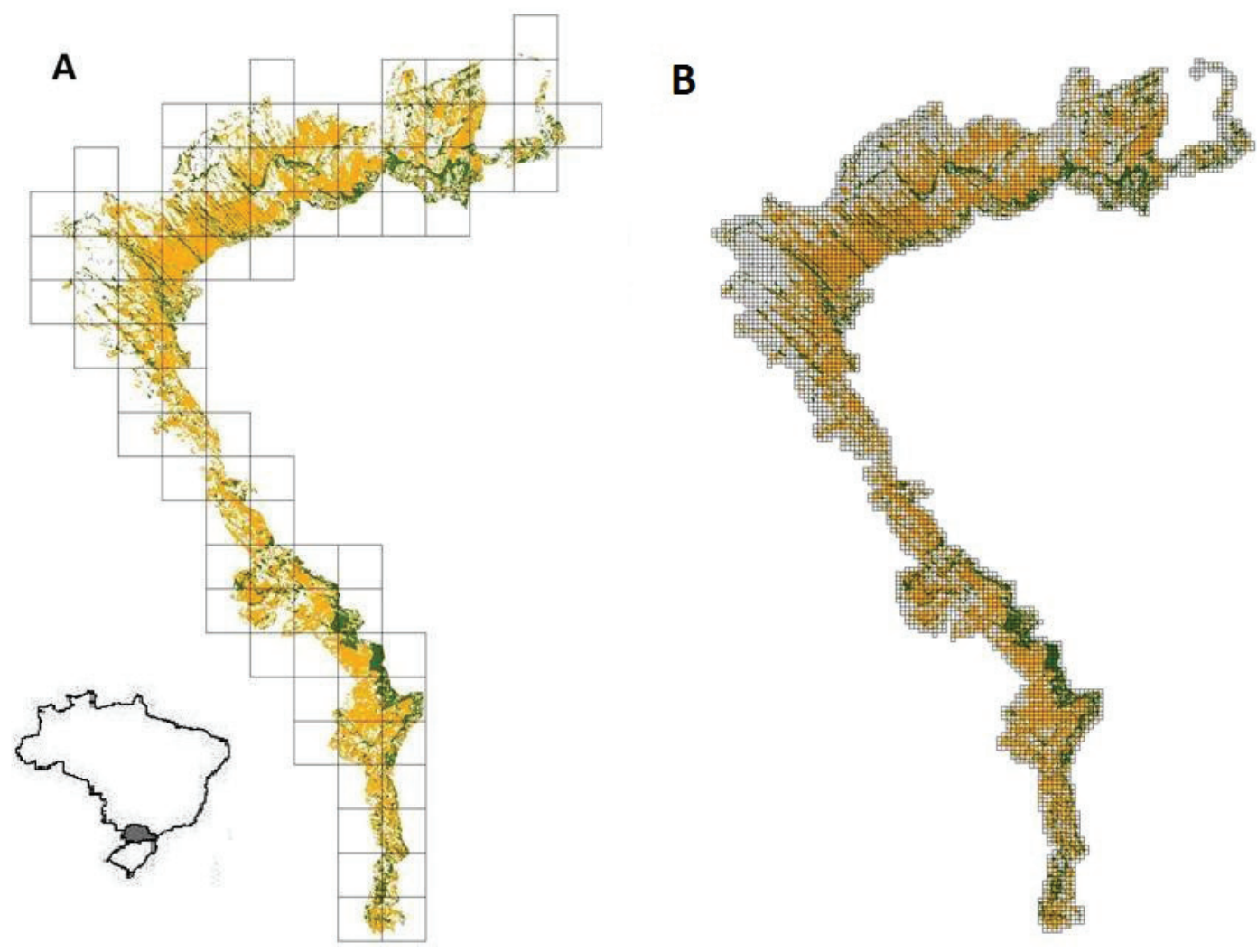

Figure 1. Natural vegetation on Escarpa Devoniana APA under $8510 \times 10 \mathrm{~km}$. A) Thiessen polygons and B) under 4,647 1x1 km grid. Vegetación natural en la Escarpa Devoniana APA bajo 85 polígonos de $10 \times 10 \mathrm{~km}$. A) Polígonos de Thiessen de $10 \times 10 \mathrm{~km}$. B) Bajo una grilla de $1 \mathrm{x} 1 \mathrm{~km}(\mathrm{~B})$. 
polygons covering almost 465,000 ha (figure 1B), including just $15 \%$ of marginal areas outside the environmental protection area.

This environmental protection area grid generated one attribute table containing 77,003 vegetation patches, where 42,083 were classified as agriculture and 8,956 as silviculture. So, almost $66 \%$ of the vegetation patches were anthropogenic. There were 12,528 araucaria forest patches, and 14,930 patches identified as grasslands and/ or savannas, and/or wetlands. After this screening, circa 1,950 quadrats $(195,000 \mathrm{ha})$ potentially could have ecotones, i.e., quadrats that presented grasslands and araucaria forests, corresponding to $22.9 \%$ of the total area.

It was necessary a visual checking on the higher resolution images of Google Earth to discriminate the grasslands areas from savanna and wetlands. In this procedure, we have found also several araucaria forest classification errors related to actual silviculture areas. Forests deeply located into canyons were desconsidered as well, due to their hypothetical difficulty to contact grasslands above. After the visual validation, only 1,544 quadrats $(18.2 \%$ of the total area) achieved the third proposed criterion for real ecotone presence in the studied scale - at least $20 \%$ of contact between grasslands and araucaria forests patches (figure 2).

The quadrats were then transposed by the research team into a*.kmz file for the project site, which allowed someone selecting them in the Google Earth platform. In the site https://sites.google.com/site/sisbiotaparana, accessing the *.kmz files, one could see a georeferenced index file with a 1 x $1 \mathrm{~km}$ grid. Sorting any one, the noted UTM coordinates allowed to access shape files of the systematic mapping where one could see the grid sequential numbers and its related attribute tables.

\section{DISCUSSION AND CONCLUSIONS}

This is a reliable method for assessing cartographic representative areas for sampling. The previous quadrats selection helps the research team on randomly sorting ecotonal areas before their field works, especially for those that do not have much local vegetation knowledge. The former $10 \mathrm{x}$ $10 \mathrm{~km}$ proposed grid is not suitable for ecotones identification in Campos Gerais region due to the finer scale required (Wu and Qi 2000). Also, the extension and convex shape of the environmental protection area lead to the selection of larger areas without interest outside the environmental protection area limits. To divide the area in a smaller grid, as 1 $\mathrm{x} 1 \mathrm{~km}$, is an option, but now we have to achieve another resolution patch. If finer images were not available, one could use the Google Earth platform (Taylor and Lovell 2012). In that case, one could be aware that, before mapping, quadrat images must be georeferenced by means of at least 10 GPS field points every sampling (Lang and Blachke 2009).

Nevertheless, even bearing ecotones, some of the quadrats may not be suitable for sampling. Each sorted quadrat should be then evaluated according to its distance and access conditions, relief, special permission entrance needs, and so on. Following Metzger (2006), a landscape
A

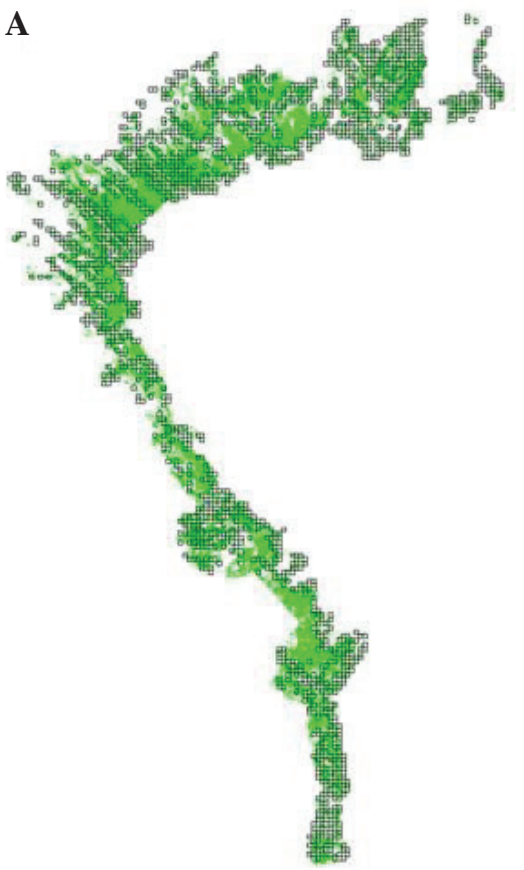

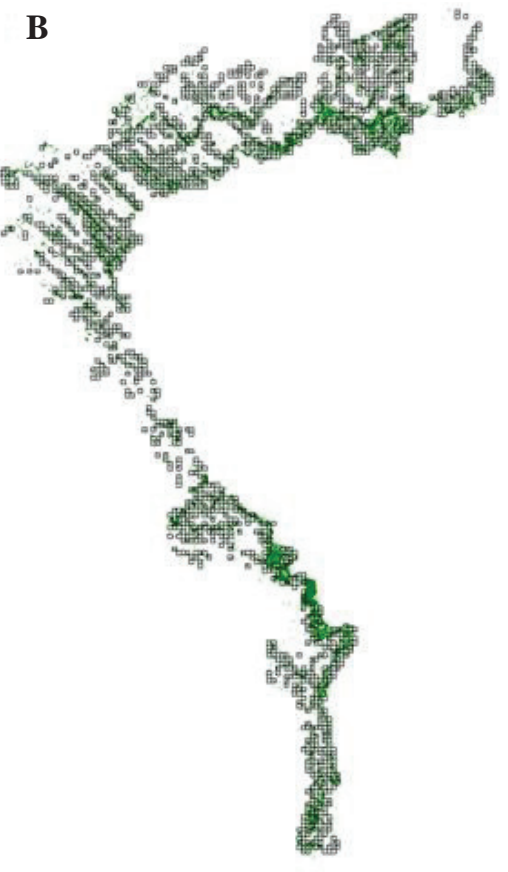

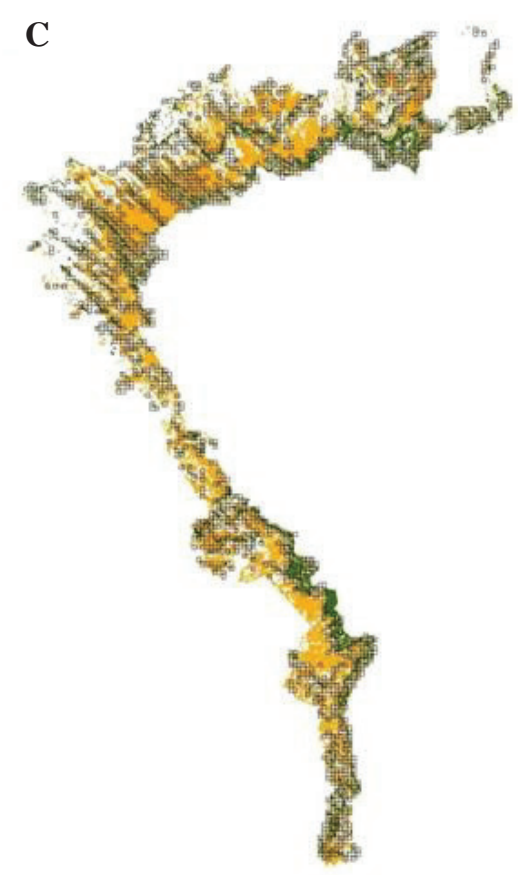

Figure 2. Vegetation remnants on a 1 x 1 km grid on the Escarpa Devoniana APA: A) grasslands, B) araucaria forests, and C) ecotonal areas. tonales.

Remanentes de vegetación en una grilla de 1 x 1 km en la Escarpa Devoniana APA. A) Pastizales. B) Bosques de araucaria. C) Áreas eco- 
context analysis should be performed as well, particularly according to spatial redundancy, connectivity or contiguity with another ecotonal area, barriers existence, or any other parameter that could possibly influence the quality of the ecotone at each focused biocoenosis.

\section{ACKNOWLEDGMENTS}

We are grateful to our colleague Atila Santana of the project Biodiversidade dos campos e dos ecótonos campofloresta no sul do Brasil: bases ecológicas para sua conservação e uso sustentável, supported by the MCT/CNPq/ MEC/CAPES/FNDCT N 47/2010 - SISBIOTA BRASIL.

\section{REFERENCES}

Behling H, M Lichte. 1997. Evidence of dry and cold climatic conditions at glacial times in tropical southeastern Brazil. Quaternary Research (48): 348-358.

Behling H, VD Pillar. 2007. Late Quaternary vegetation, biodiversity and fire dynamics on the southern Brazilian highland and their implication for conservation and management of modern araucaria forest and grassland ecosystems. Philosophical Transactions Royal Society 362: 243-251.

Curcio GR. 2006. Relações entre geologia, geomorfologia, pedologia e fitossociologia nas planícies fluviais do rio Iguaçu, Paraná, Brasil. Tesis Ingeniero Florestal. Curitiba, Brasil. Universidade Federal do Paraná. 510 p.

Duarte LS, MB Carlucci, SM Hartz, VD Pillar. 2007. Plant dispersal strategies and the colonization of araucaria forest patches in a grassland-forest mosaic. Journal of Vegetation Science 18: 847-858.

ESRI (Environmental Systems Research Institute, US). 2006. ArcGIS. The Geographic Information System for Everyone.

Lang S, T Blachke. 2009. Análise da Paisagem com SIG. São Paulo, Brasil. Oficina de Textos. 424 p.

Metzger JP. 2006. Como lidar com regras pouco óbvias para conservação da biodiversidade em paisagens fragmentadas. Natureza \& Conservação 4: 11-23.

Moro RS, MRB Carmo. 2007. A vegetação campestre nos Campos Gerais. In Melo MS, RS Moro, GB Guimarães eds. Patrimônio natural dos Campos Gerais do Paraná. Ponta Grossa, Brasil. Editora UEPG. p. 93-98.

Oliveira JM, VD Pillar. 2004. Vegetation dynamics on mosaics of Campos and araucaria forest between 1974 and 1999 in Southern Brazil. Community Ecology 5: 197-202.

Overbeck GE, SC Müller, A Fidelis, J Pfadenhauer, VD Pillar, CC Blanco, II Boldrini, R Both, ED Forneck. 2007. Brazil's neglected biome: The South Brazilian Campos. Perspectives in Plant Ecology. Evolution and Systematics 9: 101-116.

SEMA/IAP (Secretaria de Estado do Meio Ambiente e Recursos Hídricos, Instituto Ambiental do Paraná, BR). 2004. Plano de Manejo: Zoneamento Ecológico-Econômico, Plano de Manejo e regulamentação legal da Área de Proteção Ambiental da Escarpa Devoniana. Curitiba, Brasil. IAP/MRS. $350 \mathrm{p}$.

Taylor JR, ST Lovell. 2012. Mapping public and private spaces of urban agriculture in Chicago through the analysis of high-resolution aerial images in Google Earth. Landscape and Urban Planning 108: 57-70.

Wu J, Y Qi. 2000. Dealing with scale in landscape analysis: an overview. Geographic Information Sciences 6: 1-5. 